\title{
An Evaluation of the 2003 Tax Reform Effort in Brazil
}

\author{
ROGÉRIO L. F. WERNECK ${ }^{1}$
}

This paper provides an assessment of the tax-reform effort launched by the newly elected Lula government in 2003. It analyzes how the envisaged reform had to be changed and scaled down, in the wake of strong political resistance, after a failed attempt to develop a consensual proposal, fully supported by state-governors. The main effective changes are then evaluated. Challenges ahead are discussed at the end.

Keywords: tax reform; federalism; political economy; Brazil.

JEL Classification: H 20; H 7; H 77.

In early 2003, the newly-elected Lula government launched what seemed to be a resolute tax-reform effort. But the proposed reform met strong political resistance and had to be substantially changed. This paper provides an assessment of that experience. It shows how the idea of developing a consensual proposal, fully supported by state governors, proved to be much more difficult than was apparently anticipated. It also looks into how the reform had to be changed and scaled down as much of the resistance turned out to be insurmountable. The main effective changes are then analyzed.

\section{THE DEGENERATION OF THE BRAZILIAN TAX SYSTEM}

Almost forty years ago, a very commendable tax reform, including a pioneering value-added taxation scheme, was successfully implemented in Brazil. ${ }^{2}$

\footnotetext{
${ }^{1}$ Departamento de Economia, PUC-Rio. The author acknowledges support from CN Pq and helpful comments from anonymous referees. E-mail: rwerneck@econ.puc-rio.br. Submetido Setembro: 2004; aceito: M aio 2005.
}

${ }^{2}$ See Guérard (1973). 
But since the mid-sixties much of what was achieved by that refurbishment was lost, as the quality of the Brazilian tax system went through a clear and worrysome deterioration process, at least in what concerns the taxation of goods and services.

A good part of the deterioration can be attributed to changes that were entailed by the Constitution of 1988, in the aftermath of the country's redemocratization, after twenty years of military regime. Unfortunately, the long and delicate political negotiations which brought about the new Constitution took place exactly when the central government had become notably feeble. Drafted without minimum consistency guidelines, that the politically crippled executive branch was unable to press for at that moment, the new constitution failed to endow the state with a coherent mechanism to protect the interests of the majority of the population against the multiple pressures of an emerging mass democracy. Instead, it amplified the scope for the historical widespread rentseeking behavior of many segments of the Brazilian society, imposing upon the federal budget a considerable additional burden, exactly when the Union's fiscal resources were being reduced in favor of state and local governments, in the wake of a newly introduced but basically inconsistent fiscal federalism arrangement.

As the new tax system designed in 1988 was phased in during the early nineties, the central government faced growing financial difficulties. But soon, as could be expected, it started an unrelenting reaction to evade the pincer movement of shrinking revenues and swelling expenditures that had been imposed on the Union by the new Constitution. And, as often happens, increasing revenues proved to be much easier than cutting back expenditures, especially when a large part of the federal spending could not be reduced unless politically costly constitutional amendments were duly approved by Congress.

Actually, the Union's consistent effort to increase its tax revenue over the period - in order both to recover what had been lost to state and local governments and to be able to properly finance its much enlarged spending responsibilities would prove to be a tremendous success, were it not for a big problem. As the central government devised every kind of exotic taxation scheme that could raise revenues that would not be shared with lower-level governments, most of the substantial increase in the federal tax burden achieved over the last fifteen years stemmed from very low-quality taxes. M ost often that meant various forms of cascading turnover taxes, that back in the mid-sixties seemed to have been definitely eliminated from the Brazilian tax system.

At the state level, distortions of a different kind accumulated over the last three decades. Part of the difficulties also stemmed from the 1988 Constitution, that granted the states a much freer hand to introduce changes in the tax-rate structure of their value-added tax (VAT), the ICM S. ${ }^{3}$ And as most of the uncoordinated changes were in fact for the worst, they slowly transformed the pioneering, reasonably well designed, value-added taxation scheme that had been

${ }^{3}$ I mposto sobre a Circulação de M ercadorias e Serviços. 
introduced by the 1967 reform, into a confusing, disharmonic collection of 27 highly complex state-tax codes, forming an unmanageable crazy quilt of VAT arrangements. Tax-exclusive state-VAT rates imposed on some sectors, as telecommunications, have been as high as $40 \%$.

Though most states are still facing severe fiscal stringency, they have been fighting a fierce fiscal war. With some bending of the legislation, they have been competing among themselves to see which one offers the most generous tax breaks and succeeds in attracting the flashier big industrial investment projects. The collective irrationality of that fiscal war has been a source of increasing resentment among state-governors and come to be perceived by a growing number of them as the swan song of the present state-VAT arrangement.

It is easy to understand therefore why, over the last ten years, at least, there has been a growing outcry in favor of a deep change in the way goods and services are being taxed in the country. $0 \mathrm{f}$ course, that discontent has been greatly amplified with the very steep increase in the country's tax burden observed in the period. From around $25 \%$ of the GDP in the early nineties to approximately $36 \%$ in 2003.

\section{THE TAX REFORM CAM PAIGN IN RETROSPECT, 1995-2002}

In spite of all the outcry over the tax system in the mid-nineties, the Cardoso government, that took office in early 1995, remained too busy to be able to have a clear stance about the tax reform at least till late 1997. O f course, lip service continued to be paid to the importance of carrying on a bold tax reform, as had been defended since the President's electoral campaign. But the new government had at first to deal with the difficulties imposed by the M exican crisis. And, in fact, during its first months, it was deeply divided on how to react to the crisis. When it pulled itself together, as the effects of the external turmoil on Brazil proved to be less strong than anticipated, the Executive was able to extract from Congress important constitutional reforms that would open the way to the privatization of state-owned enterprises in mining, telecommunications and electricity-supply industries. But that was the relatively easy part of what proved to be a very challenging constitutional reform program. Typically, those reforms involved changing or eliminating a couple of words in the Constitution. H ow ever, there were many other much more complex reforms ahead, as the tax reform, the socialsecurity reform and the public administration reform, which required a detailed and complex redesign of the existing arrangements. And the fact is that, in 1995, the new government had no articulate detailed projects for those far more complicated reforms. It simply did not know what it really wanted from Congress.

1996 should be the year to go ahead with the pending reforms, especially when it became clear that 1995 had been marked by a very serious deterioration

${ }^{4}$ This section draws heavily from Werneck (2003a). 
of the public accounts. But the government would be completely mobilized with something else. The vast political capital, amassed in the wake of the success of the inflation-fighting program, would be mainly allocated to extracting from Congress a Constitutional amendment that would allow the reelection of the president. The Executive played a tough game and finally got the amendment approved in early 1997. But very precious time was lost, as the economy was becoming increasingly vulnerable to a less favorable external environment. ${ }^{5}$

The more optimistic analysts believed that, having assured the possibility of being reelected, and having therefore reinforced its political capital, the President would be finally ready to press Congress to move forward the required constitutional reform program. But nothing of the sort happened. Q uite to the contrary, in the second quarter of 1997, the government started to publicly discuss whether the pending reforms were in fact needed. But soon the government would be shaken back to reality, with the sudden change in the international environment caused by the Asian crisis.

In late 1997, hastily preparing an emergency fiscal-adjustment package that had to be announced in the wake of the external crisis, the federal government decided that it was about time to show a more active role in the mostly nonsensical debate on tax reform that was taking place in Congress and within the business community. At an already troubled moment, the uproar over taxes was bringing much unneeded additional bad press. Though far from prepared to present something that could resemble a detailed tax-reform proposal, the government was able to announce a sensible outline of what it considered to be the required reform.

According to that outline, the envisaged reform would concentrate on straightening out the way goods and services were taxed in country. The idea was to eliminate all forms of turnover and cascading taxes, to discard the existing federal tax on manufactured goods, to dismantle the inconsistent and distorting set of state VATs and to scrap the service tax, so poorly exploited by local governments. ${ }^{6}$ Those taxes would be replaced by three new ones: a consistent broad-based nationally-managed value-added tax, a new federal excise tax on a small number of goods and services and a local retail sales tax. A new set of

\footnotetext{
${ }^{5}$ It should be mentioned that, in what concerns the tax-reform effort, the government managed to introduce an isolated important change in 1996, with the approval of the Kandir Law (Lei Complementar $\mathrm{n}$-87), that exempted exports and capital goods from the ICM S, the state-level VAT.

${ }^{6}$ It should not only be mentioned but stressed that the government never admitted the possibility of parting with the federal tax on financial transactions. It was not included among the cascading taxes that would be eliminated. Distorting as it could certainly be, the tax would be kept with a small rate, it was argued. Being very hard to evade, it could be a source of invaluable information to tax collectors, in their effort to curb evasion of other taxes, if only Congress could pass the required legislation allowing tax authorities to have full access to detailed tax revenue data, compiled by the financial system, that could reveal the annual amount of tax on financial transactions charged to each tax payer. Such legislation was finally approved by Congress in early December 2000.
} 
revenue-sharing and compensation rules would be designed in such way as to preserve federal, state and local governments from revenue losses.

The announcement that, based on such outline, the government was preparing a detailed tax reform proposal to be eventually submitted to Congress produced a clear turnaround in the ongoing debate. The government had established a new focal point. During the next few months the federal tax authorities seemed in fact mobilized by the challenge of transforming that simple sketch of so far-reaching changes in the tax system into a minutely consistent and implementable reform project. But such mobilization would soon lose momentum.

The fiscal-adjustment package that had been announced in late 1997 had given the economy some leeway to face the shock waves of the worst part of the A sian crisis. But, in the second quarter of 1998, as soon as theexternal environment became less unfavorable again, the government proved to be confident enough to suspend a sizable part of the fiscal-adjustment measures it had so hastily announced some months before. In the wake of that fallback, the urgency that seemed to have been assigned to the tax reform disappeared. Top priority was attributed to assuring victory in the coming presidential election.

It was not a very wise move. A few months after, in August 1998, but still two months before the election, the Brazilian economy would be caught in a very vulnerable position by the shock wave of the R ussian crisis. This time it was a major shock wave, but the adoption of all relevant reacting measures had to wait for the election. When the measures were finally adopted, tough as they were, given the circumstances, they proved to befar from enough to prevent the economy from plunging in the serious foreign-exchange crisis of early 1999.

Short as it was, that scaring experience seems to have inoculated a surprising degree of conviction on the re-elected government about the need to maintain and consolidate the fiscal-adjustment measures adopted since the R ussian crisis. However, in what concerns the tax reform, the government emerged from the crisis extremely skeptical about the possibility of going ahead with the proposal outlined in late 1997. In a landmark interview to a major newspaper in midM arch 1999 the President was particularly candid on the matter, leaving no doubts whatsoever about how he was assessing the odds. He simply said that the tax reform was too complex and that he thought the country still "lacked the required consciousness" of the involved issues and interests. Pushing the reform forward would simply paralyze the parliament, so heavy were the required political negotiations. ${ }^{\text {? }}$

Crystal-clear as that position may have seem, it would soon prove be politically untenable. $\mathrm{H}$ aving put off the tax reform for his whole first term in office, the President suddenly found out that there was no political room left for explicitly putting off the reform for still another term. A fter all, if thetax reform was considered to betoo complex to benegotiated in Congress when the President was just beginning its second term, it was hard to believe that it would be seen as an easier task in

${ }^{8}$ For a more detailed analysis, see Werneck (2003a). 
2000, when the local elections campaign would naturally lead to a much hotter discussion of the involved issues. And, of course, it was even harder to believe that the reform would be perceived as a simpler challenge during the second half of the presidential term, when congressmen and governors would be involved in a complex redeployment of political forces, in preparation for the general elections of 2002. Postponing the reform to a more convenient moment would therefore almost certainly mean to leave the whole issue for the following presidential term.

In Congress, it was immediately perceived that the President's position was in fact untenable. Given the unyielding public outcry over the inadequacy of the tax system, it would be very difficult to continue to evade the whole issue, particularly in such an overt manner. Almost simultaneously, the presiding officers of both the Senate and the Chamber of D eputies made incisive declarations to the media, disagreeing with the President's stance and strongly stressing how urgent they thought a tax reform really was. Given the impending possibility of losing initiative in such an important matter to Congress, the Executive was forced to back off and to declare that the reform was in fact a top priority issue. $\mathrm{H}$ aving been obviously dragged to a battle it would rather evade, and worse, in the uncomfortable position of follower of the Congress, the Executive seemed in late $M$ arch 1999 not only unprepared for the coming action in this area but also dangerously tempted to resort to improvisation.

But, with the benefit of hindsight, one may say that, from then on, the government would deal with the tax reform as if it had decided to follow a very clear course of action. M ore precisely, perhaps one should say, a course of inaction. That does not mean at all that nothing happened. In fact, over the following eighteen months the tax-reform issue would involve a convoluted and far from uneventful game between Congress and the Executive. However, at the end of that game, the latter's strategy proved to have simply focused on a firm adherence to the stance the President had so clearly expressed before having been forced, back in $M$ arch 1999, to unwillingly play such a game with Congress. The end of the that meandering story is somewhat melancholic. But its thread was elaborate enough to involve as much as five different tax-reform proposals.

Table B.1 allows a comparison of the main features of those tax-reform proposals, all made over the period 1997-2000. ${ }^{8}$ Except for the last proposal, which seems to have been somewhat designed to bring down the curtain, all the other four have important common elements. They seem to share the same basic diagnosis on what is wrong with indirect taxation in the country. They are strikingly similar in what concerns taxes to be eliminated. And are not so dissimilar in what concerns taxes to be created. Considering that two of those proposals stemmed from the Executive and two from Congress, that seems to point out to a surprising degree of agreement on the main line of the required reform.

The guiding idea is the reconstruction of value-added taxation on broader and more rational grounds, in such a way as to allow the elimination of the turnover and cascading taxes that gained so much importance over the last decade.

\footnotetext{
${ }^{8}$ For a more detailed analysis, see Werneck (2003a).
} 
The big question was how that switching of tax base should be brought about. The involved difficulties are certainly amplified by the complexity of the Brazilian fiscal federalism, especially because value-added taxation has traditionally been the mainstay of revenue at the state level.

Looking back to what has happened between late 1997 and the end of the second Cardoso government, one may be tempted to explain the tax-reform deadlock resorting to the usual handy argument: lack of required political will in Brasília. And President Cardoso's penchant for procrastination during his first term in office makes jumping to such conclusion even more tempting. But doing so would mean to evade a deeper understanding of the difficulties and uncertainties which turned the idea of implementing a sound tax reform in Brazil into a challenge of extreme complexity.

It is against that background of a long and unsuccessful tax-reform campaign that one should analyze the first tax-reform efforts of the Administration that took office in January $2003 .{ }^{9}$

Table B.1 Tax-Reform Proposals, 1997-2000

Comparison of the Main Features

\begin{tabular}{|c|c|c|}
\hline Proposal & Taxes to be eliminated & Taxes to be created \\
\hline $\begin{array}{l}\text { Executive's Late } 1997 \\
\text { Proposal October } 1997\end{array}$ & $\begin{array}{l}\text { All turnover and cascading } \\
\text { taxes (Cofins, PIS-Pasep), } \\
\text { except tax on financial } \\
\text { transactions } \\
\text { Federal tax on manufactured } \\
\text { products (IPI) } \\
\text { State VAT (ICMS) } \\
\text { Service tax charged by local } \\
\text { governments (ISS) }\end{array}$ & $\begin{array}{l}\text { Nationally-managed VAT } \\
\text { Federal excise tax on goods } \\
\text { and services } \\
\text { Retail sales tax (IV) }\end{array}$ \\
\hline $\begin{array}{c}\text { Executive's Late } 1999 \\
\text { Proposal October } 1999\end{array}$ & $\begin{array}{l}\text { All turnover and cascading } \\
\text { taxes (Cofins, PIS-Pasep), } \\
\text { except tax on financial } \\
\text { transactions } \\
\text { Federal tax on manufactured } \\
\text { products (IPI) } \\
\text { State VAT (ICMS) } \\
\text { Service tax charged by local } \\
\text { governments (ISS) }\end{array}$ & $\begin{array}{c}\text { Federal VAT } \\
\text { State excise tax on goods } \\
\text { and services } \\
\text { Municipal retail } \\
\text { sales tax (IV) }\end{array}$ \\
\hline
\end{tabular}

${ }^{9}$ For a more extensive discussion on what comprised the tax-reform agenda in late 2002 , see Werneck (2002). 


\begin{tabular}{|c|c|c|}
\hline $\begin{array}{l}\text { Special Committee's } \\
\text { Proposal M arch } 2000\end{array}$ & $\begin{array}{l}\text { (Cofins, PIS-Pasep, CPMF) } \\
\text { Federal tax on manufactured } \\
\text { products (IPI) } \\
\text { State VAT (ICMS) } \\
\text { Service tax charged by local } \\
\text { governments (ISS) }\end{array}$ & $\begin{array}{c}\text { Dual VAT } \\
\text { (coexisting federal } \\
\text { and state VATs) } \\
\text { Municipal retail sales tax (IW) }\end{array}$ \\
\hline $\begin{array}{c}\text { Non-voted Rapporteurs's } \\
\text { Proposal March } 2000\end{array}$ & $\begin{array}{c}\text { All turnover and } \\
\text { cascading taxes } \\
\text { (Cofins, PIS-Pasep, CPMF) } \\
\text { Federal tax on manufactured } \\
\text { products (IPI) } \\
\text { State VAT (ICMS) } \\
\text { Service tax charged by local } \\
\text { governments (ISS) }\end{array}$ & $\begin{array}{c}\text { Dual VAT } \\
\text { (coexisting federal } \\
\text { and state VATs) } \\
\text { Non-cumulative excise tax }\end{array}$ \\
\hline $\begin{array}{c}\text { Executive's Proposal } \\
\text { August } 2000\end{array}$ & $\begin{array}{l}\text { Federal tax on manufactured } \\
\text { products (IPI) } \\
\text { State VAT (ICMS) } \\
\text { Service tax charged by local } \\
\text { governments (ISS) }\end{array}$ & $\begin{array}{c}\text { Federal tax on goods and } \\
\text { services (IBS) } \\
\text { Nationally uniformed } \\
\text { state VAT } \\
\text { Municipal retail sales tax (IW) }\end{array}$ \\
\hline
\end{tabular}

\section{THE 2003 PROPOSAL, GOVERN ORS AN D CON GRESS}

$\mathrm{H}$ aving decided to simultaneously push forward two politically challenging reforms - the tax reform and the social-security reform - the new Administration thought it was advisable to make sure that the newly-elected governors would support the proposed changes in both fronts. In mid-February 2003, the federal government held a two-day meeting with all governors in Brasillia in order to build consensus on the main lines of the two reforms. In what concerned the tax reform several decisions were taken. The changes to be introduced in the tax system were to be neutral, in the sense of implying neither gains nor losses to the three government levels. The main state tax, the ICM S, would be unified, the number of tax-rates drastically reduced and the 27 coexisting state codes put under a single national value-added tax legislation. Payroll taxes would be 
gradually reduced as the burden of social-security financing would be partly shifted to a new turnover tax. Following changes that had al ready been introduced in the PIS ${ }^{10}$, the Cofins ${ }^{11}$ would also be converted into a non-cumulative tax. It was also decided that the progressivity of the tax burden was to be enhanced.

\section{The 0 riginal Proposal}

It took the federal government morethan two months of intensive negotiations with governors and Congress to turn those ideas into a detailed set of proposals that could besubmitted to Congress. During the best part of that period, governors were in an uproar over whether the new ICM S should be collected in the origin or in the destination, the camp divided between "exporting" and "importing" states. Pacification required the announcement that the introduction of the destination principle would be left for a somewhat distant future. There was also a noisy discussion on how the states should be compensated for losing the possibility of waging a "tax war" among themselves in cut-throat competition for footloose investment projects.

On A pril $30^{\text {th }}$, the tax-reform proposal was finally submitted to the Congress. The core of the proposed changes involved the rationalization of value-added taxation by state governments. The ICM S was to be extensively renovated. Its administration would still be left to the states but would be made under a nationally unified framework. The number of allowed tax-rates would be limited to five. $\mathrm{N}$ ew tax incentives through the ICM S would be banned. OId ones were to be gradually phased out. The exemption of exports would be consolidated. As previously agreed, the proposal avoided the controversial idea of abandoning the origin principle, but opened the possibility of a future adoption of the destination principle.

The conversion of the Cofins into a non-cumulative tax was included in the proposal as a somewhat vague guideline, under the general idea of reducing the importance of cascading taxation and increasing the quality of the tax system. In sharp contrast with that intent how ever, another cumulative tax, the CPM F, ${ }^{12}$ would not only be preserved but transformed into a permanent tax, despite its well known distortionary effects. Along a rather similar line, the proposal recommended, as an employment stimulating measure, the eventual creation of still another turnover tax that could release payroll taxes from a sizable part of the burden of financing the social security system. $\mathrm{H}$ aving proposed a package clearly focused in the reform of indirect taxation, the government made a point of showing that the concern with the progressivity of the tax burden had not been forgotten. That explains the inclusion in the proposal, almost as an afterthought,

\footnotetext{
${ }^{10}$ Contribuição ao Programa de Integração Social.

${ }^{11}$ Contribuição para o Financiamento da Previdência Social.

${ }^{12}$ Contribuição Provisória sobre M ovimentação Financeira.
} 
of higher taxes on wealth transfers, boats and planes. O ther measures involved the devolution of rural-land taxation to subnational governments and still another extension of the DRU. ${ }^{13}$

\section{M eeting the R esistance: G overnors and Congress}

The idea that it would be possible to redesign a large part of the tax system, resorting to problematic constitutional amendments, without discussing the distribution of the aggregate tax revenue among the three government-levels, soon proved to be rather naive. Looming fiscal-federalism issues were bound to dominate the scene.

$M$ ost of the difficulties that wereto befaced stemmed from an underestimation of the fiscal predicaments that were being faced by the newly elected state governors. Since the promulgation of the Fiscal R esponsibility Law in 2000, states and municipalities have been facing hard budget-constraints. But the stringency of their fiscal situation was made even worse over the 2001-02 period. On one hand, subnational governments had to deal with the bad performance of their tax revenues in a highly adverse macroeconomic environment. $\mathrm{O} n$ the other, they had to cope with a significant rise in the real value of their debts to the Union. When their liabilities were assumed by the federal government and rescheduled for thirty years in the late nineties, the states and some large municipalities agreed with a debt-indexation clause based on the IG P-DI price index, which is heavily influenced by wholesale prices and notoriously sensitive to the exchange-rate. As the currency depreciated over the last two-years of the Cardoso A dministration, the IGP-DI decoupled from consumer-price indices and subnational governments had to deal with a fast deterioration of their indebtedness indicators. For most states, that did not imply an immediate increase in debt services, since the debtreschedule agreements signed with the Union capped those services to a given percentage of the state's net current revenue (any excess being automatically capitalized). But, for the newly elected governors, higher indebtedness meant having to face an even longer fiscal-adjustment effort, before they could comply with the guidelines established by the Fiscal Responsibility Law and be finally able to issue debt again. A rather unpromising outlook.

It was not surprising therefore that, when the tax-reform game was re-opened in Brasília in early 2003, state-governors were tempted to see it as a unique opportunity to slacken the tight fiscal constraint they were having to deal with. Suddenly, the governors' bargaining power seemed to be on the rise. The socialsecurity reform was also being launched and the federal government was counting on a strong support from state-governors. On the tax-reform front, the core of the proposed changes involved a renovation of the most important state-level tax. And thefederal government was making every effort to strengthen the coalition

${ }^{13}$ D esvinculação das R eceitas da U nião. 
in favor of the reform among state-governors, before trying to push it forward in Congress. Emblematically, in theend of A pril, Lula had summoned all 27 governors to the $\mathrm{N}$ ation's capital and, accompanied by every one of them, had crossed in person the Three-Powers Square in Brasília, from the presidential palace to the Congress building, to solemnly submit both reform proposals to the Legislative Branch. Remarkable as the ceremony certainly had been, it left an impression of consensus that did not last long.

The renovation of the ICM S itself proved to be much more controversial than the government seemed to have expected. No sooner the proposal was announced than the governors were complaining that the federal government had violated the agreement and failed to include in the envisioned changes proper compensation for revenue that would be lost by the states. In August, three months after the proposal had been announced, the Executive was facing clear difficulties to keep the reform negotiations on the right track in Congress. Discussions were being dominated by proposals of changes in revenue-sharing rules to give states and municipalities a more generous piece of the aggregate tax revenue. Governors and mayors were excited about the possibility of extracting from the Union a sizable cut of the revenue generated by the $\mathrm{CIDE}^{14}$ and the CPM F. Congressmen and governors from the northern states were pressing for an extension of the $M$ anaus Free $Z$ one until 2023. ${ }^{15}$

In early September the government gave in. It agreed with a revenue-sharing scheme that would give subnational governments a fourth of the CIDE revenue and with an extension of the $M$ anaus Free $Z$ one for another ten years. The agreements allowed the approval of a watered-down version of the initial reform proposal in the Chamber of Deputies, in a first round vote of the required constitutional amendments. But it became clear that the Senate would demand further extensive changes in the project to give it its own approval. By N ovember, with negotiations getting nowhere, the government started to look alarmed and decided it was about time to change tack. Two crucial fiscal-adjustment preserving measures, that had been tucked into the tax-reform package, had to be approved by Congress before the end of the year. The idea of converting the CPM F into a permanent tax faced insurmountable and rightful resistance in Congress and had al ready been abandoned. The government would have to settle for still another extension. But to get extensions of the CPM F and the DRU approved in time, it would have to fight against the clock.

What followed was an attempt to retreat and re-focus. The government decided to concentrate on important measures that had a real chance of being approved, and to either postpone or simply shelve the most controversial ones. It did not seem to mind when hard-to-defend measures that could be grouped under the "taxing-the-rich" label were not approved by the Senate (giving force to the

\footnotetext{
${ }^{14}$ Contribuição de Intervenção no D omínio E conômico.

${ }^{15}$ The 1988 Constitution determined that the M anaus Free Z one was to last for 25 years, until 2013.
} 
interpretation that their inclusion in the initial reform proposal had been only a question of paying lip-service). The retreating movement also involved splitting the reform proposal in two. The less controversial part was approved by the Senate and promulgated in mid-D ecember. M ore difficult measures, involving the complex renovation of the ICM S, were left to a second part. Given the envisioned difficulties, that part was divided in different modules, to be phased in over a period of up to four years, opening room for putting off delicate definitions of dissent-inducing details. The unification of the ICM S would only take place in 2005. The number of allowed tax rates would be reduced to five. The Senate would fix the rates and then sanction a consensual view of the states on how the rates should be applied to different goods and services. In 2007, the first year of the next presidential term, the ICM S would be replaced by a national broadbased value-added tax to be defined in the future. This second part of the reform, that basically outlines the renovation of the ICM $S$ and its eventual transformation into a broad-base value-added tax, was also approved by the Senate in December, but has not been ratified by the Chamber of $D$ eputies yet.

\section{ASSESSM ENT OF THE M AIN EFFECTIVE CHANGES}

What was effectively approved after all? N ot much. Curiously enough, after much excitement over constitutional amendments, it was a measure that only required an ordinary law - the conversion of the Cofins into a non-cumulative tax - that turned to be the most remarkable result of more than tw elve months of intense mobilization with the tax-reform. 0 ther approved measures involved tax relief for exports and capital goods, the CIDE revenue-sharing arrangement, further simplification of the taxation of small businesses, the eventual partial replacement of payroll taxes with turnover taxes and, of course, the extensions of the DRU, the CPM F and the M anaus Free $Z$ one. The main measures are analyzed below. ${ }^{16}$

\section{The C ofins as a N on-C umulative Tax}

The single most important outcome of the recent tax-reform effort has been the transformation of the Cofins into a non-cumulative tax. $\mathrm{H}$ aving shied away from a bolder indirect-taxation reform, that would simply eliminate the Cofins and create a consistent broad-based nationally managed value-added taxation system, the government decided to apply what was deemed an easier pragmatic fix to the problem. The main idea was to extend to the C ofins the same solution

\footnotetext{
${ }^{16}$ It should be mentioned that some measures adopted within the social-security reform could also be seen, in principle, as tax-policy changes. Payroll taxes paid on upper-bracket salaries of private-sector employees, for example, were significantly increased, as the top salary limit for social-security contribution was raised.
} 
that had al ready been adopted by the Cardoso Administration, at the very end of its second term, to turn another cascading tax, the PIS, into a non-cumulative one.

A s a matter of fact, the changes introduced in the PIS have always been seen as a pilot scheme that could eventually be extended to the Cofins. But, as so often happens with pilot schemes, the scale made a major difference. It has to be born in mind that, before the changes were introduced, the PIS was being imposed on turnover at a rate of $0.65 \%$, whereas the Cofins was being charged at theimpressive rate of $3 \%$. As could be expected, given such a wide difference, many of the difficulties that had al ready been detected when the PIS was converted have been exacerbated when the same solution was applied to the Cofins.

Turning a turnover tax into a non-cumulative tax involves an intricate calibration problem. The main idea was to allow tax payers to use credits arising from previous transactions in the supply chain. In other words, to allow them to deduct the Cofins already paid on inputs or items acquired for resale. ${ }^{17}$ The question was how to determine the exact rate that, applied to a much narrower, value-added resembling base, would generate exactly the same revenue previously collected. When the PIS was transformed into a non-cumulative tax, the $0.65 \%$ rate was raised to $1.65 \%$, the new rate being roughly 2.53 times the old one. That same multiplier was mechanically used to convert the Cofins into a non-cumulative tax. The previous 3 percent rate was raised to $7.6 \%$.

Since the new rate was announced, there has been much noise over whether $7.6 \%$ was in fact a fair rate. M ost arguments were based on what has happened to the PIS revenue after it was converted into a non-cumulative tax. The sharp increase in the inflation-adjusted revenue generated by the PIS in 2003 was presented as evidence of heavy handing in the rate setting. The tax authorities' rebuttal argued that the increase was transitory and would fade away in due time. As the change in the PIS legislation had put an end to litigations stemming from the cumulative character of the previous tax, there had been a one-off boost in the tax collection. It was also argued that tax payers would take some time to find out all the legal forms of reducing the new PIS tax bill. ${ }^{18}$ Be that as it may, as the Cofins nominal revenue in A pril 2004 was $21.25 \%$ greater than the value collected in April 2003, additional force has been lent to the evidence of a calibration error. A gain, tax authorities have defended the new rate pointing out the higher level of activity and reasons for a significant fall in tax evasion, as now the Cofins charged on services has to be withheld by the purchasing firm.

Taken together, the new PIS and the new Cofins represent a supplemental value-added tax surcharge of $9.25 \%$. C riticism of the new tax rate has been greatly amplified by the extensive sectoral redistribution of the Cofins burden entailed by the elimination of the cumulativeness. It is widely known that one of the most

\footnotetext{
${ }^{17}$ The main allowed deductions in the calculation of the new Cofins tax base involve the value of goods purchased for resale, the value of goods and services used as inputs (fuels and electrical energy included), expenses with the rental of buildings and equipment, financial expenses and depreciation.

${ }^{18}$ See Brazil. M inistério da Fazenda, Secretaria Executiva (2003).
} 
distortionary effects of a turnover tax is that it tends to fall more heavily upon goods with longer production chains. That means that, as the Cofins is turned into a non-cumulative tax, this effect is being reverted. Previously overburdened goods will be relieved, but the burden on goods with short production chains will be increased. D ramatically, in certain cases, particularly in the service sector. To some extent, this effect had already been felt when the PIS was converted into a non-cumulative tax. But again, the same conversion, applied to the Cofins, is bound to generate a much stronger sectoral redistribution of the tax burden.

As should be expected, the sheer prospect of such redistribution triggered strong political reaction. Before the law was enacted, sectors that were to be negatively affected lobbied as vigorously as they could in Brasília to introduce changes in the legislation excepting them from the heavier tax burden. Part of the lobby proved to be quite effective. Last minute changes allowed a number of sectors to continue to pay the Cofins under the old cumulative regime. The construction sector was given this privilege for two years. $O$ ther industries, mainly in the service sector, were permanently kept in the old regime. A mong others, call centers, telemarketing services, medical services, airlines, hotels and theme parks. Some products had their Cofins rate reduced to zero: agrochemicals, fertilizers, seeds, vegetables, fruits, eggs, cotton and pharmaceutical components.

There was much controversy over the treatment of agribusiness. Without much to deduct in terms of credits arising from previous transactions in the supply chain, the sector was heading to a sharp rise in its tax burden. In the legislation approved in Congress, the agribusiness was allowed to deduct as much as $80 \%$ of the Cofins bill as "presumed credits". But the change was vetoed by the President. It was argued that the agribusiness had al ready been enough relieved by the decision to grant zero-rate Cofins to a number of agricultural inputs and products. It was also pointed out that the allowance of "presumed credits" would be considered an outright subsidy in the WTO. But the controversy seems far from finished. ${ }^{19}$

There has also been considerable outcry over the inclusion of imports in the tax base of both the PIS and the Cofins. As a matter of fact, the idea was defended for a long time by the manufacturing industry: it was unfair to impose the two taxes on domestically produced goods and services but not on competitive imports. But now, as Congress has finally acceded, many industrialists are not so sure it was such a good idea after all. H igher costs of imported parts and intermediary goods may mean an ill-timed combination of squeezing margins and shrinking sales. Of course, importers of final-consumption goods will have to cope with the full impact of the $9.25 \%$ surcharge on their costs.

In fact, the effective surcharge is much greater. First, because, in the case of

${ }^{19}$ It should be noticed that, despite the veto, the President seems to have been deeply impressed by the arguments voiced by farmers. Immediately after, he admitted he had doubts about whether the changes introduced in the Cofins had been such a good idea after all. See "Lula faz autocrítica e admite rever Cofins", in: O Estado de S.Paulo, M ay 6th, 2004. 
imports, $9.25 \%$ is in fact the tax-inclusive rate. The corresponding tax-exclusive rate $t /(1-t)$ would be approximately $10.19 \%$. Secondly, because the legislation establishes that the Cofins and the PIS levied on imports should be calculated on a base comprising every other tax charged on imports, including the ICM S. But it also determines that the ICM S itself is to be levied on imports calculated on a base that includes both the PIS and the Cofins. With an 18\% ICM S rate, the effective PIS\& Cofins tax-exclusive rate would jump from $10.19 \%$ to $12.72 \%$. In practice, the calculation is even more complicated, because other taxes, besides the ICM S, have to be also taken into account. All things considered, it is an amazingly complex arrangement. In order to determine the Cofins and the PIS due in each import operation, the tax payer would have to solve a two-equation system..$^{20}$ In view of the obvious difficulties, the tax authorities had to issue a clear statement about the formulas that should be used in the calculation. ${ }^{21}$

Of course, the imposition of a such a sizable tax surcharge on imports has non-trivial trade-policy implications. It is true that the changes involve only domestic taxation. Imports were previously exempted from PIS and Cofins and now the exemption has been lifted. But whatever the good grounds the government may think it has, fact is that the effective protection of a wide range of goods and services has been substantially increased. Unsurprisingly, the first complaints have been strongly voiced within the M ercosur. But the issue will certainly be raised by other trade partners as well. For some goods and services, there may be room for an offsetting reduction of import tariffs. But what about those with very low or zero tariff? It is not clear yet how the government will deal with such problems that are being added to the country's already heavy trade-negotiation agenda.

The prospect of a sudden hike in the cost of imports has led to foreseeable anticipation movements. By the end of the first quarter of 2004, stockpiling of imports have shown up in the evolution of the trade-balance statistics. Since the charge of the PIS and the C ofins has only started on M ay $1^{\text {st }}$, the full impact on the costs of imports will only be felt by mid-year. It will mean another important inflationary shock bound to make the fine-tuning of the monetary policy even more challenging. An untimely additional difficulty.

\section{Tax Relief: Exports, Capital Goods and Small Businesses}

The consolidation of the exemption of exports from ICM S payment was one of the most important aspects of the reform. As a matter of fact, since the 1996 Kandir Law, exports have been exempted from the ICM S. But exporters remained uneasy about the possibility of losing that exemption in the wake of political

\footnotetext{
${ }^{20}$ For further details see C. Panzarini and O. B. Beija, "O 'Efeito Circular' do PIS/C ofins e do ICM S na Importação", Valor E conômico, M arch 3rd, 2004, and also "ICM S e PIS/C ofins: o milagre da multiplicação de alíquotas", Valor E conômico, A pril 30th, 2004.

${ }^{21}$ A to Declaratório Executivo SRF N o. 17, A pril 30th, 2004.
} 
pressure from state-governors. Any such fears have disappeared as the exemption was now introduced in the Constitution.

To be able to approve the amendment, the federal government had to agree with full compensation of the states for revenue losses. There has been an endless haggling over both the aggregate value of the compensations and its distribution among states (and indirectly, through revenue-sharing, municipalities). The federal government tried to limit the total amount to be compensated to $R \$ 6$ billion, but the states have been insisting on a $\mathrm{R} \$ 8.5$ billion bill. The settled value will be divided among the states according to the ratio of their exports to their ICM $S$ collection.

The conversion of the Cofins into a non-cumulative tax also opened the way to granting exports full exemption of the tax. I deally, however, the Cofins should be stripped of its social-security contribution features in order to be in fact fully deductable without raising any problems in the WTO.

Some tax relief to capital goods has also been granted. A wide range of equipments had their IPI rate reduced from $5 \%$ to $3.5 \%$. M ostly manufacturing and agribusiness machinery. ${ }^{22}$ Equipment parts were not included. The relief was in part offset by the higher Cofins tax rate, even though the government has agreed to allow the Cofins paid on capital goods to be fully deductable, as credit arising from previous transactions, over a four (instead of ten) year period. Of course, the charging of PIS and Cofins on imported equipment has pushed investment costs up.

A nother interesting tax relief measure was focused on small business. The approved legislation will still require the passing of a Complementary Law. But the idea is to create what has been called the Supersimples, an integrated simplified taxation scheme - involving tax authorities of the three government levels specially designed for small businesses. ${ }^{23}$

\section{The CIDE Revenue-Sharing Arrangement}

The CIDE, a federal tax created in 2001, to be supposedly used as an intervention tool without fiscal extraction purpose, has in fact become an excise tax charged on oil products that has generated R\$7.5 billion in revenue in 2003. The sharing of the CIDE revenue with subnational governments has been widely seen as a toll the federal government had to unwillingly pay to avoid a deadlock in the tax-reform negotiations.

After having agreed to release a fourth of the CIDE revenue to subnational governments ( $18.75 \%$ to the states and $6.25 \%$ to municipalities), the Union still tried to keep control on the use of the transferred resources. What was initially proposed was an arrangement in which resources would be earmarked to road

\footnotetext{
22 Decreto N 0. 4955/2004.

${ }^{23}$ For further details, see Silva (2005).
} 
building and maintenance, and subnational governments would have to submit to federal authorities their investment projects for approval. But Congress finally decided to give full control of the resources to subnational governments. But the earmarking to road building and maintenance was maintained.

A nother point of dispute was whether the transferred resources would be considered part of the net current revenue of subnational governments or not. As the service of the states' debt to the Union is capped as a proportion of the net current revenue, the inclusion would mean that the states would have to use a significant part of the transfers to increase their debt service payments. After a long and noisy bargaining, Congress finally decided that the transfers would be considered part of the net current revenue but the percentage of the CIDE revenue to be transferred would be adjusted upward, so as to gross up the implied increase in debt service payments. Instead of a $25 \%$ share, subnational governments would get $29 \%$. Enough for giving the states additional net spending power equivalent to $25 \%$ of the CIDE revenue. It should be noticed that Congress took a decision on that in $\mathrm{M}$ arch 2004, when the federal government was going through the worst part of a very serious political crisis, and not in the least inclined to play a tough game with governors.

Given the new revenue-sharing arrangement, it is hard to believe that the CIDE will be reverted to what was supposed to beits original role: an intervention tool without fiscal-extraction purpose. The somewhat controversial idea that the CIDE could be used as a variable tax wedge, capable of smoothing the impact of the volatility of the international oil price on domestic prices of oil products, will probably be abandoned for good. Having conquered a sizable stake in the collection of the CIDE, states and municipalities will now make all kinds of pressure to keep it as a powerful revenue generating excise.

\section{Replacing Payroll Taxes with Turnover Taxes: H ow Advisable Is It?}

In what concerns the change in the financing of social security, what was really approved was only a guideline that opens the possibility of shifting, to a new turnover tax, part of the financing burden that has been traditionally born by payroll taxes. The initiative has been defended as an employment-enhancing measure. Fortunately, no action along these lines has been taken yet. There are good reasons to believe that the change is not so advisable as it may seem. ${ }^{24}$

It should be noted in the first place that is certainly striking that, after so much effort to reduce the importance of cascading taxes, in the end the reform has given support to the creation of still another turnover tax. If at least it were a new value-added tax, the idea would be a bit less difficult to defend. But even in that case, one has to have in mind that the economy's value-added is already being overtaxed, as it became more than clear after the conversion of both the

${ }^{24}$ For a good analysis of the involved issues and a long list of misgivings, see J. Pastore, "Contribuições Previdenciárias: Da Folha para a Receita", O Estado de S.Paulo, February 25th 2003. 
PIS and the Cofins into non-cumulative taxes. As was seen above, the transformation made explicit an additional $9.25 \%$ surcharge on value-added, over and above the ICM S, the IPI and, to a certain extent, the ISS. It is not difficult to see that an even heavier value-added taxation could mean much more serious tax evasion problems. N one of those arguments becomes less valid if applied to a new turnover tax. Q uite on the contrary.

It has been also pointed out that, despite the undeniable enormous importance of the informal labor market in the country, in reasonably big firms evading and avoiding payroll taxes tend to be seen as incomparably more difficult than the evasion and the avoidance of either turnover or value-added taxes. A nother important point is that shifting the burden of social-security financing to capitalintensive industries may have undesirable effects on the competitiveness of exports. If still seen as a social-security contribution, the new turnover tax would not be deductible, according to the WTO rules. Finally, it has to be taken into account that payroll taxes have been the basic source of social-security financing all over the world. W hat has to be asked is why the proposed change has not been adopted elsewhere.

\section{M uddling T hrough: Extending the DRU and the CPM F}

The extensions of the DRU and the CPM F until 2007 could hardly be considered tax-reform measures. But they were certainly important and had become indispensable. W ithout them the current primary-balance targets would be totally unfeasible.

Since the early nineties, the high degree of revenue earmarking in the federal budget has required the adoption of off-setting measures that could allow a more effective control of public expenditures. In 1993, legislation was passed imposing an across-the-board "de-earmarking" of 20 of the total earmarked revenue. That measure was a key element of the fiscal-adjustment effort that preceded the 1994 Real Plan. The validity of the initially labeled Fundo Social de Emergência (FSE) had to be periodically extended since then. In the wake of those extensions, the "de-earmarking" legislation was re-labeled, first as Fundo de Estabilização Fiscal (FEF) and, more recently, as D esvinculação das R eceitas da U nião (DRU). As a new extension of the DRU became unavoidable, the measure was included in the fiscal-reform package.

The CPM F previously named IPM $F^{25}$ is a tax on financial transactions that could only be created to be imposed on a provisional basis, given the natural misgivings about such kind of highly distortionary taxation. The temporary character of the tax has required the periodical approval of extensions. As a matter of fact, in the original tax-reform proposal submitted in A pril 2003 to Congress, the idea was to give permanency to the CPM F. But as the resistance in

${ }^{25}$ Imposto Provisório sobre M ovimentação Financeira. 
Congress proved to be insurmountable, the government decided that still another extension would do. The CPM F will continue to be imposed on financial transactions at $0.38 \%$ rate, at least until 2007.

Important as they may have been, the extensions of the DRU and the CPM F constitute a clear cut evidence of the muddling through that still marks much of the Brazilian fiscal policy. What the two measures have in common is a tacit acknowledgement of the enormous challenges that still have to be faced in the fiscal front, in order to improve the tax system and impose higher quality to the federal expenditures. The extensions have undoubtedly given leeway to the fiscal policy, and once again saved the day in what concerns the possibility of keeping public indebtedness on a sustainable path. But, from a broader perspective, they highlight the urgent need of a bolder fiscal reform effort.

\section{CHALLENGESAHEAD}

At first sight, one would be inclined to say that the mobilization of the Lula government with the tax reform is far from over. A fter all, the approval of the measures involved in the rationalization of the ICM S, that constituted the core of the initial reform proposal submitted to Congress in A pril 2003, are still pending. But the big question is whether the government, al ready half way in the second year the presidential term, will be really inclined to mobilize as much political capital as would be required to move the complex measures forward in Congress.

W hat has to be asked then is whether a broad enough coalition could be built in 2005, when state-governors and the federal government itself will be starting to redeploy political forces for the 2006 general election. From this point of view, it is difficult to avoid skepticism about the possibility of having the pending rationalization of the ICMS approved by Congress in the current presidential term.

H ow ever, there are other considerations to be taken into account as well. The measures that were in fact approved in the 2003 tax-reform drive are having important collateral effects that deserve close attention. The transformation of the $C$ ofins into a non-cumulative tax, in particular, has contributed to make the real proportions of the economy's tax burden much more explicit and visible. And that, in turn, seems to be fueling an unprecedented widespread outcry in Brazil about both the irrationality of the country's tax system and the tax burden it entails. ${ }^{26}$ It is too early perhaps to say whether, over the coming months, such outcry will prove to be strong enough to affect the political calculus involved in the mobilization of Brasilia with tax-reform issues. But it has surely become an

\footnotetext{
${ }^{26}$ For a fuller discussion on this point, see Werneck (2003c).
} 
important factor to be monitored in the assessment of the possible evolution of the tax-reform effort in the near future.

Concern with the irrationality of the tax system and the size of the tax burden is also bound to be enhanced as growth-inducing policies start to receive more attention in the country, in the wake of the current economic recovery. That could certainly make the formation of the political coalition required to push the tax reform forward less problematic than so far it has proved to be. It is also important to have in mind that the positive effects of the economic recovery on the fiscal accounts of subnational governments may open room, in tax-reform negotiations, for a less disruptive dispute on the distribution of fiscal resources within the federation.

W hat is not clear is whether the pending proposal of a two-stage transition from the current ICM S to a broad-based nationally-managed VAT will resist the passage of time. As the reform waits for proper political conditions and becomes increasingly overdue, the roundabout idea of first rationalizing the ICM S and only then create a modern integrated VAT may become less and less defendable. The key question is for how much longer the country will be able to preserve its highly problematic state-level VAT arrangement. ${ }^{27}$ That is bound to be one of the main issues of the tax-reform debate over the coming years in Brazil. ${ }^{28}$

\section{REFERENCES}

Brazil. M inistério da Fazenda, Secretaria Executiva (2003). “Impactos da M udança do R egime de Tributação da Cofins", mimeo.

Guérard, M . (1973). "The Brazilian Value-Added Tax", Staff Papers, International M onetary Fund, Vol. 20.

Silva, A. N . (2005). "Supersimples - Análise dos Projetos sobre a N ova Tributação da M icoempresa e da Empresa de Pequeno Porte" , Consultoria Legislativa da Á rea III, Câmara dos Deputados, Brasília, mimeo.

Varsano, R. (2003). "Por uma R eforma Tributária M odelo 2004", Boletim de Conjuntura, IPEA, no. 62, pp. 69-79.

Werneck, R. L. F. (2002). "R eforma Tributária: Urgência, D esafios e Descaminhos", in: A. C. Castro (ed.), D esenvolvimento em D ebate: Paineis do D esenvolvimento Brasileiro, Rio de Janeiro: M aud/BN DES.

Werneck, R. L. F. (2003a). "Tax Reform in Brazil: Small Achievements and Great Challenges", in: J. A. González, V. Corbo, A. O, Krueger and A. Tornell (eds.), L atin A merican M acroeconomic R eforms: The Second Stage Chicago: The University of Chicago Press.

Werneck, R. L. F. (2003b). "Lançamento M alsucedido", O Estrado de S.Paulo, O ctober $10^{\text {th }}$, 2003.

Werneck, R. L. F. (2003c) “Exacerbando as Contradições”, O Estrado de S.Paulo, D ecember $19^{\text {th }}, 2003$.

\footnotetext{
${ }^{27}$ For an elaboration of the argument that the country cannot afford any more the preservation of a state-level VAT, see Werneck (2003b).

${ }^{28}$ For a broader analysis of the pending tax-reform agenda, see Varsano (2003) and Werneck (2002).
} 